\title{
EXPLORE
}

\section{Sistem Pendukung Keputusan Penerima Bantuan Covid 19 menggunakan Metode Simple Additive Weighting (SAW) (Studi Kasus : Desa Sundawenang)}

\author{
Falentino Sembiring, Mohamad Tegar Fauzi, Siti Khalifah, Ana Khusnul Khotimah, \\ Yayatillah Rubiati \\ Fakultas Teknik Informatika dan Komputer \\ Jurusan Sistem Informasi \\ Universitas Nusa putra \\ Sukabumi Regency, Indonesia \\ falentino.sembiring@nusaputra.ac.id,mohamad.tegar_si17@nusaputra.ac.id, siti.khalifah_si17@nusaputra.ac.id, \\ ana.khusnul_si17@nusaputra.ac.id, yayatillah.rubiati_si17@nusaputra.ac.id
}

\begin{abstract}
Abstrak-Upaya Pemmerintah memberikan bantuan sosial agar terpenuhinya semua kebutuhan ekonomi bagi masyarakat yang terkena dampak virus covid-19 ternyata masih dirasa belum optimal. Sehingga banyak masyarakat yang berpikir bahwasannya bantuan sosial yang dilakukan tidak dan belum tepat sasaran dan Pemerintahpun mengakui masalah tersebut, sampai saat ini kemensos dan pihak pemda masih memperbaharui data agar tepat sasaran. Kasus tersebut diduga karena pengumpulan data yang tidak sesuai fakta dan tidak real time di setiap daerah.

Pengimputan data secara manual di Desa Sundawenang beresiko tidak tepat sasaran, adanya penerima ganda serta terdapat oknumoknum yang memanfaatkan keadaan tersebut. Oleh karena itu metode Simple Additive Weight (SAW) diharapkan dapat menentukan kriteria masyarakat yang berhak menerima bantuan sosial COVID-19. Metode SAW merupakan metode yang menggunakan perhitungan atau yang menyediakan jenis-jenis kriteria tertentu yang memiliki bobot hingga nilai akhir yang berbobot akan menjadi keputusan akhir.

Perhitungan Simple Additive Weighting (SAW) mengacu pada kriteria masyarakat yang layak menerima sesuai data yang relevan. Dari hasil perhitungan yang sudah dinormalisasi nilai yang tertinggi berhak menerima bantuan sosial 1,525 yaitu $5 \%, 1,425$ yaitu $15 \%$ dan 1,375 yaitu $35 \%$. Kemudian yang tidak berhak menerima dengan nilai $<1,375$ yaitu $45 \%$. Sistem pendukung keputusan penerima bantuan sosial COVID-19 ini diharapkan bisa menentukan keputusan akhir agar mempermudah penyaluran penerima yang sesuai sasaran.
\end{abstract}

Kata Kunci: Sistem Pendukung Keputusan, Simple Additive Weighting, Bantuan COVID-19

\section{Pendahuluan}

Di tengah wabah virus Corona atau Covid-19 di Indonesia berdampak kepada sejumlah aspek kehidupan. Terjadinya ketidaksetabilan perekonomi di berbagai negara tak hanya soal kesehatan, penyebaran wabah yang bermula dari Tiongkok ini juga berdampak juga pada aspek ekonomi terutama pada saat di berlakukan penerapan pembatasan social distancing dan lockdown.

Bertambahnya angka pengangguran yang semakin meningkat karena PHK atau diberhentikan sementara akibat masa pandemi ini, sebagian dari masyarakat yang terkena dampak terpaksa kehilangan pekerjaannya termasuk UMKM dan pedagang kecil turut mengalami kesulitan ekonomi.

Guna mencegah krisis ekonomi maka pemerintah memberikan stimulus kepada masyarakat yang terdampak berupa bantuan sosial untuk meringankan biaya hidup sehari hari dengan memberikan bantuan sosial berupa bantuan uang tunai maupun non tunai kepada masyarakat. Dan pemerintah sudah mempersiapkan akan memberikan bantuan khusus bagi masyarakat yang terpapar dampak virus covid-19 guna meminimalisir pengeluaran masyarakat dimasa pendemi ini. Selain itu, dilansir dari situs resmi Sekretariat kabinet, bahwa bagi masyarakat non jabodetabek akan diberikan bantuan sosial tunai. Dimana pemerintah melibatkan 9 juta KK, diutamakan masyarakat yang belum menerima bansos apapun, dengan bantuan uang senilai Rp600.000/bulan dengan jangka waktu 3 bulan dimana anggaran yang disiapkan sebesar Rp16,2 triliun.

Namun berjalannya program tersebut di lapangan ternyata tak sesuai ekspektasi, dana bantuan sosial tersebut tak sesuai harapan masyarakat karena bantuan 
sosial tersebut dianggap salah sasaran atau tidak tepat sasaran menurut masyarat. Hal ini dapat dibuktikan dengan adanya keluh-kesah dari masyarakat yang memang seharusnya layak mendapat bantuan tetapi tidak menjadi sasaran mendapat bantuan tersebut.

Perlunya mengevaluasi kembali program bantuan yang di berikan pemerintah agar lebih tepat sasaran karena program-program tersebut tidak berjalan sesuai yang dicanangkan sebelumnya oleh pemerintah. Seperti halnya di Desa sundawenang ini banyak masyarakat yang mengeluh akan bantuan sosial yang tidak tepatsasaran. Diduga karena kabupaten/kota atau pihak terkait tidak memperbaharui data kemiskinan atau data masyarakat yang layak menerima bantuan sehingga data menjadi tidak akurat dan dana yang dikucurkan pemerintah pun tidak tepat sasaran. Dalam penelitian yang kami lakukan di Desa Sundawenang pada tanggal 10 s/d 14 Agustus tahun 2020, bahwa data keseluruhan penerima bantuan Covid19 yakni 624 orang dan yang baru menerima yakni berjumlah 161 orang (26\%), jadi total yang belum menerima bantuan yakni 463 orang ( $74 \%$ ).

Karena masih banyak tumpang tindih data banyak orang yang sudah meninggal ternyata menjadi sasaran yang mendapat bantuan tersebut sehingga sangat jelas sekali jika bantuan sosial tersebut tidak tepat sasaran. Dalam melaksanakan pemilihan penerima bantuan Covid-19 pun di Desa yang penulis teliti sebagai bahan pertimbangan yaitu Desa Sundawenang ini mengalami berbagai kendala seperti banyaknya pengajuan penerima bantuan tidak sebanding dengan kuota yang ada dan yang seharusnya tidak layak mendapat bantuan malah mendapat bantuan, begitupun sebaliknya. Untuk membantu pihak terkait agar lebih efektif memilih masyarakat yang membutuhkan dan yang terdampak agar tepat sasaran sebagimana yang diharapkan semua masyarakat yang ada di Desa Sundawenang ini sesuai dengan data yang akurat dan relevan.

\section{Dasar Teori}

\section{A. Sistem Pendukung Keputusan}

Menurut (simangnsong dan sinaga 2019), Ada empat tahap yang saling berhubungan dan saling berurutan dalam mengabil keputusan. Empat proses tersebut adalah:

\section{Intelligence}

Kecerdasan dapat didefinisikan dalam banyak pemahaman: pemahaman logika, kecerdasan diri, pembelajaran, pengetahuan empsional, penalaran, perencanaan, kreatifitas, pemikiran kritis, dan pemecah masalah. Secara umum ini dapat di gambarkan sebagai kemampuan untuk mempersipsikan sebuah informasi, dan mempertahankannya sebagai pengetahuan yang di terapkan

\section{Design}

Disain adalah rencana untuk spesifikasi untuk kontruksi objek atau system untuk implementasi suatu kegiatan atau proses, atau hasil dari rencana atau speifikasi itu dalam bentuk prototype, produk dan proses, kata kerja mendisain mengekspresikan proses pengembangan suatu sistem.

\section{Choice}

Tahap ini di lakukan untuk menentukan sebuah pilihan dari berbagai aspek pencarian, efaluasi dan penyelesaian yang di buat sesuai model yang telah di rancang. Penyelesaian dengan menerapkan sebuh model adalah nilai spesifik dari alternatif yang terpilih.

\section{Implementation}

Implementasi di terapkan apda teknologi untuk menggambarkan interaksi unsur- unsur dalam bahasa pemrograman, penerapan di gunakan untuk mengenali dan menggunakan elemen kode atau sumber daya pemrograman yang di tulis kedalam program. Model simon menjelaskan alur dari sebuah sistem dengan memanfaatkan adanya informasi yang ada adapun penerapan model spk adalah :

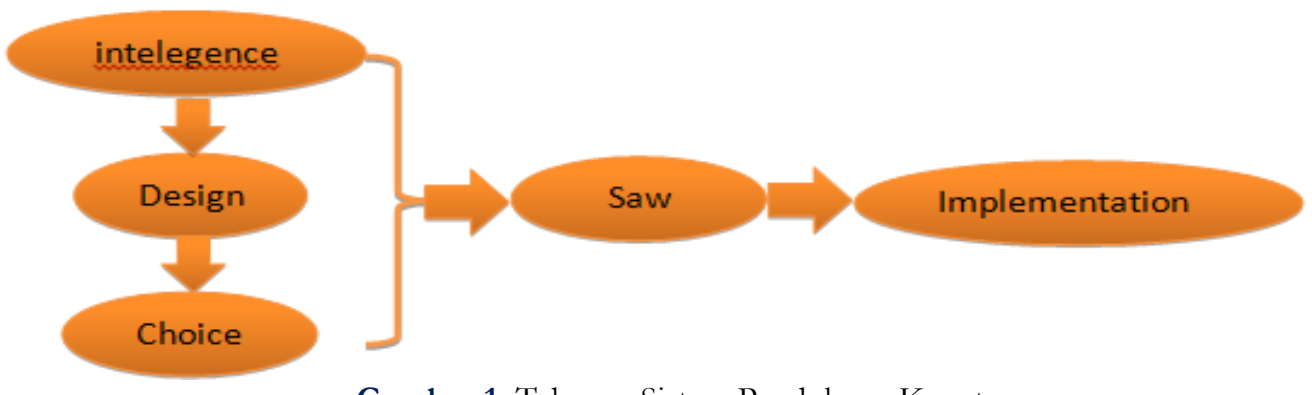

Gambar 1. Tahapan Sistem Pendukung Keputusan

Dalam ke empat tahapan di atas menjelaskan teknik dalam penerapan sistem pendukung keputusan berdasarkan alur di atas mempunyai peranan untuk menghasilkan sebuah keputusan yang tepat. Intelligence merupakan hasil dari false kontribus dari sistem. Choice merupakan fase yang di gunakan untuk membuat sebuah pemilihan sebuah kriteria yang tepat sebagai pendukung dalam mngambil sebuah keputusan. Design merupakan fase hasil dari kontribusi dari intelegence dan design. Pengambilan yang di buat dalam peentuan keputusan yang terdiri dari beberapa tindakan yang di jadikan sebagai alternatif dalam mencapai beberapa tujuan sesuai dengan yang sudah di tetapkan.[1] 


\section{B. Bantuan Sosial}

Bantuan sosial yang dilakukan pemerintahan di Indonesia sebelumnya sudah pernah dilakukan, tetapi kebanyakan tidak membahas secara spesifik tentang bantuan sosial di era pandemi COVID-19 ini. Beberapa penelitian terkait permasalahan dalam penyaluran bantuan sosial baik dimasa pandemi COVID-19 maupun sebelum pandemi. Mufida (2020) dalam artikelnya tentang "Polemik pemberian bantuan sosial di tengah pandemi COVID19", Dalam banyaknya jenis pintu bantuan sosial yang di keluarkan pemerintah daerah jakarta menyebabkan kekisruhan di karnakan pendataan calon penerima yang kurang tepat sasaran dan pembagian bantan sosial lainnya di bagikan tidak serentak Kemudian Joharudin et al. (2020) dalam artikelnya yang berjudul "Panic Syndrom COVID-19": Penekanan Terhadap Kebijakan Yang Diberikan Pemerintah" menyebutkan bahwa kebijakan lain yang diberikan Pemerintah yakni memberikan Bantuan Langsung Tunai (BLT) untuk setiap kepala rumah tangga yang dinilai kurang mampu. Tidak hanya itu, masyarakat juga berbondong-bondong untuk mengumpulkan dana bantuan yang nantinya akan dikumpulkan dan ditukar dengan bahan pokok. Bahan pokok ini akan diberikan untuk masyarakat yang kurang mampu juga. Pemerintah juga mulai membagikan bantuan sosial kepada masyarakat. Namun, pelaksanaan ini membuat terjadinya penolakan di beberapa wilayah. Bagi wilayah yang menolak, mereka beralasan memiliki kekhawatiran banyak masyarakat yang tidak tercatat sebagai penerima Bantuan Sosial ini.

Bentuk peduli dan tanggung jawab dari pemerintah terhadap fakir miskin dan anak-anak terlantar adalah dengan memberikan bantuan sosial dan sistem jaminan sosial bagi seluruh rakyat kalangan bawah dan memberdayakan masyarakat yang lemah dan tidak mampu.

Sebuah kondisi dimana optimalnya kebutuhan masyarakat dari berbagai segi kebutuhan diantaranya kebutuhan sandang, pangan, spiritual dan sosial warga negara sehingga mampu melaksanakan fungsi sosialnya itu disebut adanya Kesejahteraan Sosial dan hal ini menjadi tumpuan bahwa suatu negara dengan pemerintahan yang berhasil. Hal ini tertera dalam pasal 34 ayat 1 UUD RI thn 1945 yang berisi Teramantkannya sebuah kewajiban negara mampu memelihara fakir miskin dan anak tetlantar untuk mendapatkan hak2nya sebagai warga negara seeperti rehabilitas sosial, jaminan sosial, pemberdayaan sosial dan perlindungan sosial dimana sebagai bentuk kewajiban negara yang harus terpenuhinya semua hak2 atas kebutuhan dasar menjadi warga negara yang miskin pun tidak mampu.

Kita ketahui bahwa Pasal 17 ayat 3 UUD RI tahun 1945, UU No.39 tahun 2008 tentang Kementrian Negara( Lembaran negara RI tahun 2008 No.166, tambahan lembaran negara RI No.4916), Peraturan pemerintah lengganti UU No.1 tahun 2020 Tentang Kebijakan keuangan negara dan stabilitas siatem keuangan Penanganan pendemi Corona virus Disease 2019 serta dalam rangka menghadapi ancaman perekonomian nasioanl dan stabilitas sistem keuangan (lembaga negara RI tahun 2020 No.87, tambahan lembaran negara RI No.6485), peraturan Presiden No.28 tahun 2015 tentang kementrian keuangan (lembaran negara RI tahun 2015 ,No.51) serta peraturan menteri keuangan No.38/PMK.02/2020 tentang pelaksanaan kebijakan keuangan Neggara untuk penanganan Covid-19 dan menghadapi ancaman yang membahayakan perekonomian nasional, dan Stabilitas sistem keuangan (Berita negara RI thn 2020 No.382) Yang merupakan hukum yang sah yang menjadi dasar hukum utama ditetapkan nya PMK 43/2020 [2].

\section{Simple Additive Weighting (SAW)}

Metode Simple Additive Weighting (SAW) adalah metode penjumlahan yang memiliki nilai bobot. Yang mencari bobot nilai paling berbesar dari rating kinerja pada setiap alternatif pada semua atribut. Metode SAW membutuhkan proses normalisasi matriks keputusan untuk membandingkan dengan semua rating alternatif yang ada [3].

\section{Metodologi}

Metode penelitian pada dasarnya merupakan cara ilmiah untuk mendapatkan informasi dengan tujuan dan kegunaan tertentu. Metode penelitian merupakan cara yang digunakan oleh peneliti dalam mengumpulkan data penelitiannya. Cara ilmiah berarti kegiatan penelitian ini didasarkan pada ciri-ciri keilmuan yaitu rasional, empiris, dan sistematis. Metode penelitian ini digunakan sebagai pedoman penelitian dalam pelaksanaan penelitian agar hasil yang dicapai tidak menyimpang dari tujuan yang telah ditentukan sebelumnya.

\section{A. Metode Pengumpulan Data}

Metode pengumpulan data yang digunakan dalam penelitian ini, antara lain :

\section{Observasi}

Observasi yang kami lakukan adalah dengan mengamati secara langsung situasi dan kondisi di desa sundawenang agar mendapatkan informasi untuk di jadikan bahan penelitian.

\section{Wawancara}

Metode wawancara di lakukan secara langsung untuk mengetahui apa yang di butuhkan peneliti. Wawancara di lakukan dengan menanyakan langsung kepada staff desa sundawenang tentang pendataan bantuan covid 19 .

\section{B. Metode Simple Additve Weighting}

Metode Simple Additive Weighting adalah metode yang mencari nilai terbesar rating kinerja dari setiap alternatif dan atribut.

Berikut ini adalah tahapan metode Simple Additive Weighting :

1. Menentukan kriteria untuk dijadikan acuan dalam mengambilan keputusan.

2. Menentukan tingkat penerapan setiap alternatif menurut standar masing-masing 
3. Membuat matriks keputusan, dan melakukan normalisasi matriks sesuai dengan jenis atribut cost/benefit sehingga menghasilkan nilai matriks yang ternormalisasi $r$.

4. Hasil akhir dari proses sortasi dengan mengitung perkalian matriks $\mathrm{r}$ ternormalisasi dan vektor bobot untuk memilih nilai maksimum sebagai alternatif solusi terbaik

5. Dari hasil akhir normalisai kemudian di urutkan dari nilai maksimum ke nilai minimum.

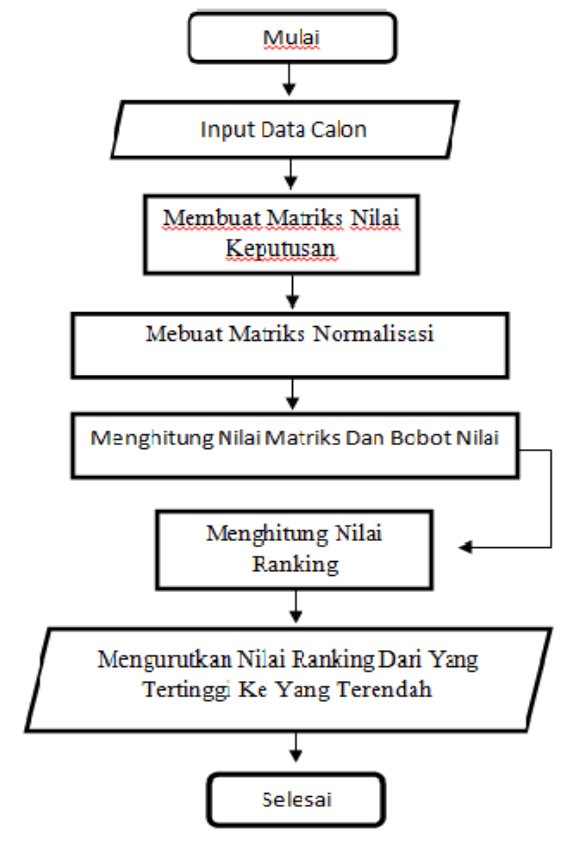

Gambar 2. Flowchart Perhitungan Metode Saw

\section{Hasil dan Pembahasan}

Berdasarkan gambar 2. Flowchart Perhitungan Metode SAW di atas, langkah awal dalam perhitungan metode SAW adalah dengan mengambil beberapa sampel calon penerima bantuan dan setelah itu kita memasukan nama calon penerima bantuan. langkah selanjutnya menentukan kriteria-kriteria calon penerima bantuan. masing-masing kriteria di beri simbol dan di beri nilai bobot. Kemudian setelah di beri nilai bobot selanjutnya kriteria diberi nilai bobot presentase dari kriteria c1 sampai ke n. sehingga apabila semua bobot presentase kriteria di jumlahkan akan menghasilkan nilai bobot presentase bernilai 1. Dan kemudian Langkah selanjutnya menentukan cost atau benefit dari setiap kriteria. Setelah itu kita membuat tabel alternatif dan memasukan nilai bobot dari setiap calon. Setelah memasukan niai bobot dari setiap calon selanjutnya kita melakukan tahap normalisasi. Dan dari hasil normalisasi tersebut menghasilkan nilai akhir normalisasi. kemudan hasil akhir normalisasi di urutkan dari nilai yang terbesar sampai nilai yang terkecil seperti gambar tabel 1 di bawah ini.

Tabel 1 Hasil Normalisasi Terurut

\begin{tabular}{ccc}
\hline No & Alternatif $(\mathrm{Ai})$ & Nvi Terurut \\
\hline 1 & Cicih Junarsih & 1,525 \\
2 & Ee Kuraesin & 1,425 \\
3 & Irawan Kurniawan & 1,425 \\
4 & Yeni Suryani & 1,425 \\
5 & Elin Lusianti & 1,375 \\
6 & Rahmanudin & 1,375 \\
7 & Iok Partiah & 1,375 \\
8 & Adang Setiawan & 1,375 \\
9 & Matalih & 1,375 \\
10 & Cicih & 1,375 \\
11 & Sadiah & 1,325 \\
12 & Gusnaeni Janawi & 1,25 \\
13 & Nurjaya & 1,225 \\
\hline
\end{tabular}




\begin{tabular}{lcc}
\hline 14 & Yanti Widiyanti & 1,175 \\
15 & Yadi Rusyadi & 1,125 \\
16 & Kayat & 1,075 \\
17 & Yumanah & 0,85 \\
18 & wiswa D.A & 0,725 \\
19 & Budi Somantri & 0,65 \\
20 & Deri Amalia Sagita & 0,65 \\
\hline
\end{tabular}

Di bawah ini adalah diagram dari hasil akhir normalisasi terurut. Pada bagian diagram yang berwana coklat tua sampai bagian diagram yang berwarna coklat muda menujukan, dan dari nilai 1.525 sampai 1.425 ada $5 \%$ orang yang mendapat bantuan, dan dari 1.425 sampai
1.375 ada 15\%, kemudian orang yang bernilai 1.375 ada 35\% Dan bagian tabel yang berwarna pink dari nilai 1.375 kebawah menujukan ada $45 \%$ orang yang belum terpilih mendapatkan bantuan.

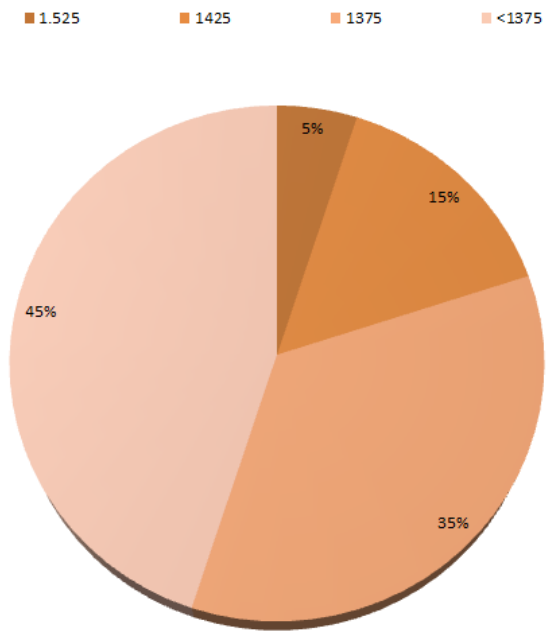

Gambar 3. Diagram Hasil Akhir Normalisasi Terurut

\section{Kesimpulan}

Pogram bantuan sosial yang diberikan pemerintah untuk penanggulangan pandemi COVID-19 masih kurang efektif karena tidak tepat sasaran. Di masa pandemi ini, semua bantuan sosial harus disalurkan segera dengan menggunakan data yang ada. Namun, data yang digunakan seringkali tidak akurat sehingga permasalahan penerima tidak tepat sasaran tidak dapat dihindari. Informasi dan pengetahuan tentang jenis-jenis dan syarat penerima bantuan sosial sudah emestinya diinformasikan secara terus menerus kepada petugas kewilayahan dan

\section{Daftar Pustaka}

[1] Tonni Limbong. Muttaqin. Akbar Iskandar.Agus Perdana Windarto. janner Simarmata. Mesran. Oris Krianto Sulaiman. Dodi Siregar. Dicky Nofriansyah. Darmawan Napitupulu. Anjar Wanto., Sistem pendukung keputusan metode dan implementasi. Yayasan Kita Menulis, 2020.

[2] W. Rahmansyah, R. A. Qadri, R. T. S. Ressa, A. Sakti, and S. Ikhsan, "Pemetaan Permasalahan Penyaluran Bantuan Sosial Untuk Penanganan Covid-19 Di Indonesia," 2020.

[3] A. D. L. Intan Putri Pratiwi, FX. Ferdinandus, "CAHAYA téch," vol. 8, no. 2, 2019, [Online]. Available: masyarakat. Oleh karena itu dengan adanya sistem pendukung keputusan penerima bantuan covid-19 menggunakan metode Simple Additvie Weighting (SAW) dengan kriteria-kriteria yang sudah di tetapkan, hasil dari nilai prankingan yang terbesar yang berhak mendapat bantuan sosial tersebut. Sehingga dapat meminimalisir kecurangan dan membantu mempermudah pihak di Desa sdawenang dalam menyeleksi atau memilih calon penerima bantuan sosial agar tepat sasaran

https://ojs.cahayasurya.ac.id/index.php/CT/article/ view/46.

[4] M. P. Rahastine, S. Mayasari, and N. Sasmita, "Strategi Public Relations Pt Indotama Karya Gemilang Dalam Meningkatkan Pemahaman Proses Prosedural Tenaga Kerja Indonesia," Cakrawala - J. Hum., vol. 19, no. 2, pp. 237-242, 2019, doi: 10.31294/jc.v19i2.6487.

[5] D. Di, K. Kitamura, M. Ridwan, and C. Putra, "Naskah publikasi." 2017.

[6] I. Riyansuni and J. Devitra, “ Analisis Dan Perancangan Sistem Pendukung Keputusan Penerima Bantuan Pangan Non Tunai (BPNT) Dengan Simple Additive Weighting ( SAW ) Pada Dinas Sosial Kota Jambi ,"'J. Manaj. Sist. Inf., vol. 5, no. 1, pp. 151-163, 2020. 